\title{
Water uses in sustainable agriculture practices: reconsidering the priorities in water scarce areas
}

\begin{abstract}
In this opinion paper, the complex issues associated with a sustainable use of water in agriculture are reviewed. Using the example of countries which suffer from acute water stress, the author assesses the evolutions which have led the agricultural sector to a situation where water uses are not sustainable anymore. Further, the possibilities to implement different agricultural water uses policies are discussed particularly based on adding value to rainfall and reconsidering the types of crops sown. Moreover, the promotion of crop yields in rainy seasons and crop/livestock association in farming systems is acknowledged to be a major step to increase water productivity and avoid groundwater depletion, although it may entail more labor uses as well as capacity building programs.
\end{abstract}

Keywords: crop yields, groundwater depletion, labor, rainfall, water
Volume 8 Issue 4 - 2018

\author{
Mohamed Taher Sraïri \\ Senior animal science lecturer, Hassan II Agronomy and \\ Veterinary Medicine, Morocco
}

\begin{abstract}
Correspondence: Mohamed Taher Sraïri, Senior animal science lecturer, Hassan II Agronomy and Veterinary Medicine,
\end{abstract} P.O. Box 6202, Rabat, 10101, Morocco, Email mt.srairi@iav.ac.ma

Received: August 10, 2017| Published: August 02, 2018

\section{Introduction}

Water sustainable uses have certainly become a global issue, to ensure a rapid growth of food production, in order to feed 9 billion people by $2050 .{ }^{1}$ In water stressed areas, as in the Middle East and North Africa (MENA) countries, the average annual water availability levels have dropped to less than $700 \mathrm{~m}^{3}$ per capita, and the issue of agricultural water uses has become a crucial one. Moreover, climate change is already emphasizing the effects of water stress, as expected levels of rainfall are due to fall significantly, whereas average temperatures might rise by $2^{\circ} \mathrm{C}$ in the coming decades. ${ }^{2}$ Such parameters imply that future agricultural policies will have to be revised to cope with the reduction in water availability. In this opinion paper, the possibilities to adapt agricultural policies to water stress are discussed. The panorama of possible interventions is presented, whether based on irrigation techniques as well as on-farm sustainable water uses.

\section{Drip irrigation: a clear example of the existing gap between potential and actual performances}

In most of the MENA countries, irrigation is mandatory to guarantee crop yields, particularly during the summer season. This situation is the consequence of a rising water demand due to increased cultivated areas with crops that require high volumes of water (particularly orchards), when there is no rainfall at all, and when temperatures can reach $45^{\circ} \mathrm{C}$ and more. In such a situation, two kinds of solutions have been promoted to alleviate constraints: groundwater use and the conversion of irrigation from farrow to drip systems. In theory, these measures seem interesting, but in reality they are far from being efficient. As a consequence, groundwater depletion has become of growing concern. Recent studies in the Saïss plain (North Center of Morocco) have shown that drip irrigation does not necessarily induce an improvement of water use efficiency. ${ }^{3}$ Moreover, drip irrigation exacerbates the gap between farmers with important financial means, who can invest in deeper boreholes and who will contribute more to groundwater depletion, and farmers with limited capital who may not be able to continue to access deeper groundwater. ${ }^{4}$ As a consequence, the level of social and economic disparities may increase between households, implying more social exclusion for many smallholder farmers whose only fate will be to exit from the agricultural sector.

\section{Water productivity in agriculture: a multi-faceted concept with complex implications}

In order to deal with scarce water availability, recent research results have focused on the need of a paradigm shift in the field of agricultural practices. The promoted solutions should in priority rely on the use of rainfall (blue water) as the possibilities to increase the irrigated areas have come to a limit. Moreover, the use of water has to be assessed on a cost efficiency scale. This has recently prompted the emergence of the water productivity concept, which does not only rely on the volumes of water used to get food (i.e. $\mathrm{m}^{3}$ of water per kilogram of food), but also the origin of the water and even more the gross margin behind each $\mathrm{m}^{3}$ of water used and the edible nutrients it produces (whether kcal or kg of proteins). When assessing such water productivity parameters for each crop, methodological difficulties may have to be sold, linked to crop prices volatility and agricultural practices variability among farms. In a recent research program conducted in the Saïss plain, where annual average rainfall levels do not exceed $500 \mathrm{~mm}$, it was demonstrated that the assessment of the cattle products (milk and live weight gain) water footprint was a complicated task, as it required considering a series of production functions on-farm: from water with its diverse sources (rainfall, surface and groundwater irrigation, as well as virtual water - i.e. the volumes of water needed to produce purchased feed for cattle and which has been used elsewhere-) to fodder biomass and finally to milk and meat outputs which are produced simultaneously by the same herds. Moreover, the same research emphasized that milk and meat had a very limited impact on groundwater, ${ }^{5}$ as they relied mainly on rainfall and virtual water (i.e. purchased feed). Such results imply that cattle are crucial components of agricultural systems in semiarid areas, providing high value protein products and also supplying farmers with manure; a key component of sustainable farms, with less pesticide uses. ${ }^{6}$ Moreover, crop/livestock association is an efficient way to add value to labor assets in smallholder units, where limited capital often impedes the intensification of crop yields. In addition, farm gate milk and live animals prices are quite steady, whereas crop prices volatility 
may hinder the overall hypothesis that irrigated summer crops, such as fruit trees and vegetables increase water economic productivity.

\section{Conclusion}

Most of the MENA countries face significant problems related to water scarcity and climate change will further increase these problems. Significant changes in agricultural policies are required in order to find solutions to the growing water demand. To avoid a mining exploitation of groundwater resources which will further hinder the sustainability of farming systems in many regions, public policies will need to implement genuine regulation policies. Current policies have actually exacerbated the gap between rich and poor farmers, and between a minority of large farms and the vast majority of smallholder units. In the near future, agricultural policies need to recognize the importance of an integrated and diversified agriculture. Policy makers should understand that rural and agricultural development implies dealing with complex affairs that cannot be solved just by simplistic measures, such as heavy investments in drip irrigation and groundwater exploitation as well as the promotion of cash crops for export. Agricultural policies have to take into account the complementarities and interactions between rain-fed and irrigated systems, between crops and livestock, and their consequences on labor uses and its remuneration. To do so, a paradigm shift has to take place. This entails a renewed interest to rain-fed systems and to a better use of rainfall, particularly in the production of cereals, pulses, fodder and crop/livestock association. There have to be specific efforts dedicated to select crop varieties using efficiently rainfall and adapted to support drought. This shift in paradigm also requires acknowledging the key role of smallholder farmers. Specific capacity-building programs can improve their skills and technical know-how about sound agricultural practices, in order to improve crop and livestock yields and to increase water productivity as well as their incomes to avoid rural exodus.

\section{Acknowledgements}

None.

\section{Conflict of interest}

The author declares there is no conflict of interest.

\section{References}

1. Mancosu N, Snyder RL, Kyriakakis G et al. Water scarcity and future challenges for food production. Water 2015;7(3):975-992.

2. Parry ML, Rosenzweig C, Iglesias A, et al. Effects of climate change on global food production under SRES emissions and socio-economic scenarios. Global Environmental Change. 2004;14(1):53-67.

3. Benouniche M, Kuper M, Hammani A, et al. Making the user visible: analyzing irrigation practices and farmers' logic to explain actual drip irrigation performance. Irrigation Science. 2014;32(6):405-420.

4. Ameur F, Kuper M, Lejars C, et al. Prosper, survive or exit: Contrasted fortunes of farmers in the groundwater economy in the Saiss plain (Morocco). Agricultural Water Management. $2017 ; 191: 207-217$.

5. Sraïri MT, Benjelloun R, Karrou M, et al. Biophysical and economic water productivity of dual-purpose cattle farming. Animal. 2016;10(2):283291.

6. Lechenet M, Dessaint F, Py G, et al. Reducing pesticide use while preserving crop productivity and profitability. in arable farms. Nature Plants. 2017;3. 